\title{
Settlement of Commercial Disputes in the World Trade Organization (WTO)
}

\author{
Ma'en Juwaihan \\ Faculty Of Law- University Of Petra, Amman - Jordan
}

\begin{abstract}
The WTO Dispute Settlement Body is the cornerstone of the multilateral trading system. It is instrumental in stabilizing the global economy, it is a tool for resolving disputes and enforcing rules related to the organization, and makes the trading system safer and predictable. This system is based on clearly defined rules with a timetable for the hearing of the case.But this does not prevent the existence of disadvantages related to this body in terms of the way it operates and the threats related to the termination of the presence of the Appeal, which in turn may lead to the failure of the global system for the settlement of trade disputes between the countries of the world.
\end{abstract}

Keywords: commercial disputes, World Trade Organization, WTO.

DOI: $10.7176 / \mathrm{JLPG} / 91-12$

Publication date: November $30^{\text {th }} 2019$

\section{Introduction}

In view of the weakness and ineffectiveness of the dispute settlement system under the GATT 1947, it was necessary to establish a new system for the settlement of trade disputes in order to avoid the shortcomings and gaps in the GATT.

Therefore, a new system based on effective and specific rules and procedures for the settlement of trade disputes between member states was sought. This was achieved in the Uruguay Round, which was in the agreement establishing the World Trade Organization, which was signed in Marrakech in 1994.

The Memorandum of Understanding establishes stricter discipline with regard to the time allowed to settle the case as well as flexible deadlines for the various stages of the procedure. He stressed that an early and proper solution was essential for the functioning and effectiveness of the WTO. ${ }^{1}$

The main change that occurred as a result of the memorandum of understanding on rules and procedures governing the conduct of disputes (DSU) was the judicial method of settling disputes through the establishment of the Dispute Settlement Body (DSB), the Permanent Appeal Panel, which Symbolized by (AB).

Settlement of trade disputes is one of the main activities of the WTO. This Convention has established a Memorandum of Understanding on the rules and procedures for the dispute settlement process. This system is based on the principle of the rule of law in conflict resolution and provides security and predictability in the multilateral trading system. ${ }^{2}$

Members recognize that this system preserves the rights and obligations of members under the covered agreements $^{3}$

The Memorandum of Understanding on Rules and Procedures Governing the Conduct of Disputes shall include all Members who administer dispute settlement procedures. As such, the DSB will negotiate dispute settlement, appoint arbitration teams to resolve disputes, and decide whether to accept or reject the decisions of the Permanent Appellate Body (AB).

The Memorandum of Understanding (DSU) guarantees the implementation of judgments and decisions and may authorize punitive measures in case of non-compliance with the rules set out in the Memorandum of Understanding. ${ }^{4}$

With regard to developing countries, the WTO dispute settlement mechanism promotes equality among States in resolving disputes between their members. They are provided with additional legal procedures and assistance, which are available throughout the dispute resolution process and the implementation of resolutions and recommendations. ${ }^{5}$

\footnotetext{
1. Shaffer, Gregory C. and Elsig, Manfred and Puig, Sergio, The Law and Politics of WTO Dispute Settlement (March 16, 2016). The Politics of International Law, eds. Wayne Sandholtz \& Christopher Whytock, Oxford University Press, 2016; UC Irvine School of Law Research Paper No. 2016-10. Available at SSRN: https://ssrn.com/abstract=2748883 . last accessed on 7 February 2019

${ }^{2}$ Hadi Talaat Hadi Al-Tai, the provisions of the Convention establishing the World Trade Organization and its impact on the development of international trade, Dar Arab Renaissance, Cairo, 2013, p. 411.

${ }^{3}$ Article 3, paragraph 2, of the Memorandum of Understanding on rules and procedures governing the settlement of disputes

${ }^{4}$ Whereas Article 21 (7) of the Memorandum of Understanding affirms the rules and procedures governing the settlement of disputes (DSU);

"The DSB, when the subject of the issue is a developing country member, should consider what additional measures it can take to suit the circumstances."

${ }^{5}$ Available on The WTO website http://www.wto.org/english/tratop_E/dispu_e/disp_settlement_cbt_e/c11s2p1 e.htm last accessed on 25 December 2018
} 
Constraints on developing countries in the WTO dispute settlement process are constraints of legal knowledge, financial capacity, and political power. ${ }^{1}$

The WTO dispute settlement mechanism showed criticism and reservations from some WTO members, most notably the reservations and observations made by the United States on reform of the WTO dispute settlement body system that would upset the rules of the WTO judicial arm upside down. ${ }^{2}$

\section{The criteria adopted for the settlement of disputes:}

\subsection{Equity, speed, efficiency and mutually acceptable solution:}

A dispute arises when a country adopts a trade policy or other measure that one or more WTO members consider a violation of WTO agreements or a breach of its obligations. Or because of the misinterpretation of the provisions of international trade agreements, a third group of States may state that they have an interest in this dispute and acquire certain rights.

Article (21) paragraph (8) of the Memorandum of Understanding stipulates the rules and procedures governing the settlement of disputes (DSU) as follows: "The Dispute Settlement Body shall, in cases where the case is a developing country member and, when considering appropriate action, may take into account not only the commercial agreement covered by the proceedings in question but also its effects on the Developing countries are also concerned".

It should be noted, however, that these judgments are not mandatory and should be considered as a recommendation for consideration when the dispute is settled by the arbitration teams. ${ }^{3}$

The WTO has one of the most active international dispute settlement mechanisms in the world. Since 1995, the World Trade Organization (WTO) has been active, more than 500 disputes have been submitted to the WTO and more than 350 resolutions have been issued. ${ }^{4}$

However, it was not a question of judgment but priority was to settle disputes through consultations. As of January 2008, the number of cases that have reached the full completion stage is 136 except for other cases performed amicably and some cases are still in the extended consultation phase. ${ }^{5}$

The WTO dispute settlement system is based on several principles, including adherence to the GATT 1947 settlement system through the use of independent dispute resolution experts, the use of established procedures with previous work experience and the participation of the WTO Secretariat through the provision of technical support. To settle immediately and satisfactorily, which requires equality between the rights and duties of members. ${ }^{6}$ It must also respect international trade agreements and the WTO's goal, and act in good faith when using settlement procedures, because it is understood that a request for conciliation or dispute settlement is not intended to be adversarial and may not be considered as such. ${ }^{7}$

The WTO law is based on its statute on the possibility of taking countermeasures against the violating member, which is a means of pressure, with the aim of obliging the member whose legislation violates the memorandum of understanding to amend it. In addition to strict and automatic deadlines for the adoption of Parties' reports, which undoubtedly enhances the security and predictability of the international trading system. When the parties to a dispute fail to find a settlement to the dispute, the Arbitration Commission or the Permanent Appellate Body is supposed to resolve the dispute amicably ${ }^{8}$

The Memorandum of Understanding in Article 2, paragraph 3, emphasized the importance of this system as a central element in providing security and predictability in the multilateral trading system. Members recognize that this system preserves the rights and obligations of members under the covered agreements, and clarifies the existing provisions of these agreements in accordance with the usual rules of interpretation of public international law, bearing in mind that the recommendations and decisions of the DSB do not add to the rights and obligations set forth in the Agreements covered but not diminished. Article 3 of paragraph (7) also states: "...

\footnotetext{
${ }^{1}$ Bahri A., "Using dispute settlement partnerships for capacity building: Bangladesh's triumphant experience at WTO DSU", (Journal of International Trade Law and Policy, 2019), Available on https://doi.org/10.1108/JITLP-07-2018-0028. last accessed on 7 February 2019

${ }^{2}$ Gantz, David A., An Existential Threat to WTO Dispute Settlement: Blocking Appointment of Appellate Body Members by the United States (July 15, 2018). Arizona Legal Studies Discussion Paper No. 18-26. Available at SSRN: https://ssrn.com/abstract=3216633 or http://dx.doi.org/10.2139/ssrn.3216633. Last accessed February 7, 2019.

${ }^{3}$ H T Pham, 'Developing counties and WTO the need for more mediation in the DSU', 9 Harv. Nrgot. L. Rev.347 2004

${ }^{4}$ WTO Dispute Settlement: Statistics. Available on The WTO website : https://www.wto.org/english/tratop e/dispu e/dispustats e.htm last accessed on 6 February 2019

${ }^{5}$ https://www.wto.org/french/thewto f/whatis f/tif f/displ f.htm

${ }^{6}$ Article 3, paragraph 3, of the Memorandum of Understanding on the rules and procedures governing the settlement of disputes

${ }^{7}$ Article 3, paragraph 10, of the Memorandum of Understanding on the rules and procedures governing the settlement of disputes

${ }^{8}$ Article 23, paragraph 1, of the Memorandum of Understanding provides for rules and procedures governing the conduct of disputes to prohibit the use of unilateral acts to correct any breach of obligations contained therein (when members seek to correct a breach of obligations or other types of cancellation or disruption of interests). Established under the covered agreements, it shall resort to and adhere to the rules and procedures of this Understanding. Tetyana Payosova \& Gary Clyde Hufbauer \& Jeffrey J. Schott, 2018. "The Dispute Settlement Crisis in the World Trade Organization: Causes and Cures," Policy Briefs PB18-5, Peterson Institute for International Economics
} 
in the absence of an agreed solution, the first objective of the dispute settlement mechanism is usually to ensure that the proceedings concerned are withdrawn if they are found to be inconsistent with the provisions of any of the agreements covered."

WTO members agree to use the multilateral dispute settlement system instead of taking unilateral action if they believe other members violate trade rules, in other words, states should implement agreed procedures and respect their judgments ${ }^{2}$

Under the old GATT there was no specific timetable for conflict resolution and it was easy to prevent decisions and many cases to continue without a solution. Disputes were settled under the GATT in two ways, either through diplomatic negotiations or through judicial settlement or commercial arbitration.

The WTO has maintained diplomatic means in the settlement of disputes, known in international law as conciliation, mediation and good offices. ${ }^{3}$

\subsection{Characteristics of the dispute settlement system:}

The characteristics of the dispute settlement system are multiple:

Inclusive property: Article 1 of the Memorandum of Understanding provides that the rules and procedures of this Understanding shall apply to the Agreement Establishing the World Trade Organization, the Understanding on Dispute Resolution and Agreements on Trade in Goods, Services Trade and Trade-Related Aspects of Intellectual Property Rights.

Prohibition of resorting to unilateral acts: States are bound by the Memorandum of Understanding, that is, they cannot resolve their trade dispute based on their domestic law ${ }^{4}$

The property of continuity and sustainability: The WTO's Dispute Settlement Body is characterized by a lasting nature in terms of work, and is the most efficient organ of the WTO to act swiftly to address urgent trade problems, which fall within the WTO's mandate.

The system is also characterized by the existence of a permanent body of appeal and the application of the concept of transparency, so that consultation requests are accessible to all Members of the Organization ${ }^{5}$

In case of failure, the members shall circulate the request for settlement to establish the arbitration teams and inform the members when the difference report is adopted or rejected by the Appellate Body. Conflicting parties shall have the right to access all documents throughout the conflict. ${ }^{6}$

Automatic adoption of special group reports, Article 16, paragraph 4, of the Memorandum of Understanding states that: "The Panel shall adopt the report of the Panel at one of its meetings within 60 days after the date of the circulation of the report to the members unless a Party notifies the Panel of its decision to appeal or the Panel decides by consensus not to adopt the report. ${ }^{7}$

This text indicates that the Settlement Body automatically adopts the reports of the special teams unless one of the parties to the dispute formally informs them of their decision to appeal and does not wish to adopt this report. The Uruguay Round Memorandum of Understanding also prevents the State from obstructing the adoption of its resolution.

Under the old GATT procedures, decisions could only be taken by consensus, so that only one opposition would be sufficient to prevent them. Decisions are now taken automatically unless there is unanimity in rejecting them and therefore any country wishing to block a decision should bring together all other WTO members, including the opposing party to the dispute, to take their views.

The WTO dispute settlement system can be automatic; because of the way it operates on the basis of the principle of passive unanimity that the report should be accepted only if it is unanimously rejected, also bearing in mind that once the dispute begins, the process cannot be stopped. Settlement without the consent of all parties concerned $^{8}$

One of the salient features of the WTO dispute settlement system is that decisions reached once adopted by the DSB need to be followed or the Permanent Appellate Body ${ }^{9}$

\footnotetext{
${ }^{1}$ Look at that. Bossche, P., The Law and Policy of the World Trade Organisation 'Text, Cases, and Materials', (2nd ed, Cambridge University Press, 2009) page 172

${ }^{2}$ Article 23, paragraph 1, of the Memorandum of Understanding provides for rules and procedures governing the conduct of disputes to prohibit the use of unilateral acts to correct any breach of the obligations contained therein (when members seek to correct a breach of obligations or other types of cancellation or disruption of established interests. Under the Agreements covered, they shall abide by and adhere to the rules and procedures of this Understanding.

${ }^{3}$ See Article 5 of the Memorandum of Understanding on rules and procedures governing the conduct of disputes.

${ }^{4}$ See Article 23, paragraph 1, of the Memorandum of Understanding on rules and procedures governing the conduct of disputes

${ }^{5}$ See Article 4, paragraph 1, of the Memorandum of Understanding on rules and procedures governing the conduct of disputes

${ }^{6}$ Galal Wafa Mohammadin, Settlement of International Trade Disputes under GATT Agreements, New University Publishing House, Alexandria 2004, p. 24

${ }^{7}$ Article 16, paragraph 4, of the Memorandum of Understanding on the rules and procedures governing the settlement of disputes.op.cit.

${ }^{8}$ Yerxa, R., and Wilson, B., Key Issue in WTO Dispute Settlement: First Ten Years, (Cambridge University Press 2005) page 30

9 . Bossche, P., The Law and Policy of the World Trade Organisation 'Text, Cases, and Materials', (2nd ed, Cambridge University Press, 2009) page 178
} 
This procedure is very similar to the judicial system, but it is best to encourage the countries concerned to discuss their problems and settle the conflict themselves. The first step, therefore, is consultation between the Governments concerned, even at later stages, consultation and mediation can always be made, and states can only resort to the DSB only after making sure that this is the only option for resolving the dispute.

Article 3, paragraph 2, of the Memorandum of Understanding states that: "Members shall recognize that such a system shall preserve the rights and obligations of Members under the agreements covered.

This body also has the character of neutrality and independence in terms of form, subject to a specific set of legal rules and the existence of specific mechanisms for the functioning of the Dispute Settlement Body, and in making its decision independently without objection or external interference. Nor can the WTO dispute settlement body intervene in any dispute except with the consent of the conflicting parties. The manifestations of such consent are, for example, the possibility of filing lawsuits or resorting to good offices and arbitration to settle disputes, which require the consent of the parties in dispute.

The Rules of Procedure of the DSB shall precisely specify the procedure to be followed and the timetables to be followed for the settlement of the dispute, which shall not initially last for more than one year or more than 15 months if there is an appeal. Agreed deadlines are flexible and in case of emergency (perishable products) the procedure is accelerated to the maximum extent possible. ${ }^{1}$

The DSU is flexible in this regard. In addition, countries can resolve their differences themselves at any time. These are the total figures for dispute resolution.

60 days for consulting and mediation phase.

45 days to set up the team and appoint group members

6 months for the submission of the final report of the dispute study team to the parties concerned.

3 weeks to submit final report to WTO members

60 days for adoption of the report by the DSB (if there is no appeal).

Total $=1$ year (without appeal)

60-90 days to submit appeal report

30 days for the adoption of the appeal report by the DSB

Total $=1$ year and 3 months

\section{WTO dispute resolution mechanism:}

\subsection{WTO dispute resolution phase}

The DSB is a body responsible for resolving trade disputes between WTO members. It has exclusive jurisdiction to establish "teams" of experts to examine the case and approve or reject the Commission's conclusions or the outcome of the appeal process. It monitors the implementation of decisions and recommendations and takes interim measures in case of non-implementation of the obligations. The DSB authorizes the suspension of concessions and other obligations under the covered agreements and has the power to authorize action against a member who does not comply with a decision. The DSB shall meet as required and as provided in Article 2, paragraph 3, of the DSU, and decisions shall be taken by consensus.

That is, if there is no objection from one of the representatives of the Member States of the Organization present at the meeting.

A member who is absent at this meeting shall not have the right to invoke his opposition to the resolution in his absence.

Conflict resolution has several stages, as follows:

Stage 1: Consultations (up to 60 days): This phase is diplomatic ${ }^{2}$ It is a compulsory procedure and a key stage for the settlement of disputes before further action and the parties to the conflict must discuss with each other whether they can reach an agreement. This procedure is stipulated in Article IV of the Memorandum of Understanding and also in Article 4, paragraph 11, of the DSU.

Paragraph 11 of the same Article has given importance to the activation of the role of consultation by saying that if a member of the Consultation is deemed to have a substantial commercial interest in consultations held pursuant to Article 22, paragraph 1, of GATT 1994, or Article 22, paragraph 1, of the Agreement other covered, This Member may notify the Consultating Members and the Bureau within 10 days from the date of the circulation of the request for consultations under the said Article of his desire to join the consultations. In case of urgency, the parties shall enter into consultations in less than ten days and if no settlement is reached within 20 days, the complaining party shall have the right to take further action.

If this compulsory procedure (consultations) does not work, optional means such as good offices, conciliation and mediation under international law may be used. The Director-General of the WTO may be asked

\footnotetext{
${ }^{1}$ Leslie Johns and Krzysztof J. Pelc, "Fear of Crowds in World Trade Organization Disputes: Why Don't More Countries Participate?," The Journal of Politics 78, no. 1 (January 2016): 88-104.

${ }^{2}$ Mohammed Khalil Al-Mousa, Judicial Position of International Organizations, Human Rights, Environment and International Trade Settlement Bodies, Wael Publishing House, Amman, 2003, p. 100
} 
to intervene as an intermediary or in any other way, but the time limits for consultations must be exhausted before any other mechanism is used.

Phase II: The DSU granted Member States the right to request the establishment of a special committee to consider its complaint after the failure of friendly means, (The time limit for establishing the committee is 45 days and the group has six months to complete its work)

The offending State may prevent it from doing so for the first time but at the second meeting of the DSB it is not entitled to prevent such objection (unless there is a consensus against the establishment of the Special Committee). ${ }^{1}$

The task of the task force is to assist the DSB in formulating decisions or recommendations. However, since its report can only be rejected by consensus in the DSB, it is difficult to reverse its conclusions, which should be based on the group's findings through the conventions invoked.

The final report is sent to the parties to the conflict within six months. In case of emergency, when it comes to perishable products, this period is reduced to three months. The Memorandum of Understanding sets out in detail the working procedures of the committees and the main steps as follows:

Before the first meeting, each party to the dispute submits written arguments to the Committee. The first meeting relates to the complainant's and defense's arguments to the complaining State or States. Respondent and other States expressing interest in the dispute submit their arguments at the first meeting of the Committee, and States concerned submit written responses and oral arguments at the second meeting of the Committee.

If a Party raises scientific or technical issues, the Committee may consult the experts or appoint a group of experts to prepare an advisory report.

The team provides both parties with descriptive sections (facts and arguments) a preliminary draft report and gives them two weeks to comment on. This report does not contain findings and conclusions. The Committee then submits an interim report containing its findings and conclusions to both parties who have one week to request a review.

The review phase should not exceed two weeks. During this period the committee may hold further meetings with the parties. A final report will be sent to both parties and after three weeks it will be distributed to all WTO members.

If the Panel finds that the complaint is in fact inconsistent with the WTO Agreement or the WTO obligation, it recommends that this action be taken in accordance with WTO rules and can suggest how to do so.

This report becomes a decision within 60 days or a recommendation by the DSB unless there is unanimous disapproval. Preliminary decisions are taken by the Committee and approved (or rejected) by all WTO members with the possibility of challenging these decisions.

\subsection{Appeal by appeal:}

Each party may appeal against the decision of the Special Committee and in some cases it may be appealed by both parties. The appeal must be based on legal points such as legal interpretations and not a review of existing evidence or consideration of new cases.

The WTO Appellate Body is known as the Permanent Appellate Body (AB), which is set out in Article 16 of the Memorandum of Understanding on Rules and Procedures Governing the Conduct of Disputes (DSU).

The members of the Permanent Appellate Body are appointed every four years and are composed of seven members representing the majority of WTO membership. The Appellate Body members are experienced in international trade and have a reputation and professionalism. Moreover, these members must be free from any association of any government. ${ }^{2}$

Each appeal is dealt with by three of the seven members of a permanent appeal body established by DSB and its representative on a wide range of WTO components.

The members of the Appellate Body shall be appointed for a term of four years, and shall be persons whose authority is recognized in the field of law and international trade and not related to national administration.

The hearings of the Appellate Body shall be held in private and shall not be attended by the parties, in accordance with the provisions of Article 17, paragraph 10 of the DSU, which states that "The Appellate Body's proceedings shall be confidential in the light of the information and evidence provided.

The appeal may lead to confirmation, modification or reversal of the Commission's findings and legal conclusions, and the duration of the procedure should in principle not exceed 60 days and in any case 90 days. The DSB shall accept or reject the Appellate Body's report within 30 days with the possibility of rejection by consensus only.

Decisions of the Appellate Body are final and binding and are generally respected by the parties to the conflict. Since its establishment in 1995, the WTO's Dispute Settlement Body has resolved a large number of

\footnotetext{
${ }^{1} J o h n s$, L., Thrall, C. \& Wellhausen, R.L. Rev Int Organ (2019). https://doi.org/10.1007/s11558-019-09364-y

2 . UNDERSTANDING THE WTO: SETTLING DISPUTES A unique contribution

Available on http://www.wto.org/english/thewto e/whatis e/tif e/disp1 e.htm last accessed on 25 December 2018.
} 
trade disputes and has earned a reputation as the "jewel of the crown" in the world trade system". ${ }^{1}$

\subsection{Implementation of Appellate Body recommendations and decisions.}

Delay in the implementation of the recommendations and decisions of the Appellate Body is a violation of the decision by the breaching party and must provide compensation or be subject to appropriate and severe punishment even if it is not a real punishment, but it is "corrective action" During a certain amount of time to do it.

The Memorandum of Understanding states that "in order to effectively resolve disputes for the benefit of all Members it is necessary to comply immediately with the recommendations or provisions of the DSB.

The DSB shall supervise and supervise the implementation of recommendations and decisions, with the right of members to challenge the implementation of recommendations and decisions, even if after adoption

This appeal is then placed on the DSB's agenda and remains so until it is resolved. Before each DSB meeting. The Member concerned should submit a written report detailing the progress made in implementing the recommendations. ${ }^{2}$

For developing countries, the DSB should improve monitoring of implementation through additional actions commensurate with the circumstances ${ }^{3}$

However, the Member concerned may claim compensation and suspend the concessions made as an interim measure when the recommendations and provisions are not implemented within a reasonable time.

However, this is no better than the full and proper implementation of the recommendations. Such interim measures are implemented to expedite the implementation of recommendations, relying on a punitive procedure for such dispute settlement, and can be counterproductive to the complainant. There is no problem in implementation if the complaining party is a developed or powerful country, where it can implement without thinking of retaliation against the causing State, especially in areas that have nothing to do with international trade.

If a country is a weak state, such as developing or least developed countries, it can implement without worrying of retaliation by a country of the same or lesser degree, but it cannot implement in absolute terms if it is against a higher state such as developed countries. It has economic, military and political advantages.

In principle, the State must declare its good faith in implementing the recommendations contained in the Panel's report or the Appellate Body's report. And declare its intention to do so at the DSB meeting within 30 days of the adoption of the report.

If it is not possible for that country to comply immediately with the recommendation, a reasonable time will be given to do so. If the State does not comply during this time, it should enter into negotiations with the complaining country or countries in order to find satisfactory compensation for the parties, for example tariff reductions in areas of particular interest to the complaining party.

If satisfactory compensation is not agreed after a period of 20 days, the complainant may request the DSB's authorization to retaliate ("suspend ... application of privileges or other obligations"). This procedure, which is supposed to be temporary, is aimed at encouraging the other State to comply. For example, this could be to prohibit imports by increasing import duties on products from the other country beyond agreed ceilings to high levels, so that imported products become too expensive to sell - all within certain limits.

The DSB must grant such authorization within 30 days of the end of the "reasonable period of time" unless there is unanimity in rejecting the request.

In principle, retaliation should be in the same sector as the subject of the dispute, if that is not possible or effective.

It could target another area of the same convention and if that was not possible and the circumstances were too serious, action could be taken under another agreement. The aim is to minimize the likelihood that the action will affect other sectors while ensuring its effectiveness. ${ }^{4}$

In all cases, the DSB monitors the implementation of the decisions made and the outstanding work remains on its agenda until the matter is resolved.

\section{Disadvantages of the dispute settlement system By judicial means in the WTO}

The dispute settlement process takes a long period of time, causing economic damage to the complainant, especially when the complaint is under consideration. The party making the complaint does not resort to interim measures and procedures that protect its interests during the settlement of the dispute ${ }^{5}$

\footnotetext{
${ }^{1}$ Tetyana Payosova \& Gary Clyde Hufbauer \& Jeffrey J. Schott, 2018. "The Dispute Settlement Crisis in the World Trade Organization: Causes and Cures," Policy Briefs PB18-5, Peterson Institute for International Economics.2018.

${ }^{2}$ See Article 21, paragraph 6, of the Memorandum of Understanding on rules and procedures governing the conduct of disputes (DSU.(

${ }^{3}$ See Article 21, paragraph 7, of the Memorandum of Understanding on the rules and procedures governing the conduct of disputes (DSU.(

${ }^{4} \mathrm{https}$ ://www.wto.org/french/thewto_f/whatis_f/tif_f/disp1_f.htm

5 The World Trade Organisation, A Handbook on WTO Dispute Settlement System, Cambridge University Press.
} 
Because there is no compensation system for the winning party to recover the legal expenses it has incurred during the course of the proceedings and to claim compensation for the economic losses incurred during the settlement of the dispute, which would do great harm to less wealthy developing countries.

In accordance with Article (22) of the Memorandum of Understanding relating to the rules and procedures governing the conduct of disputes (DSU). If the recommendations are not implemented or fail to be implemented within the time period specified by the violating State, the Memorandum provides temporary remedies to the affected States, such as compensation and suspension of concessions or obligations in the WTO.

These temporary remedies remain in effect until the violating State has fully implemented the previous recommendations, which means that there are no immediate solutions.

The punitive measures in the WTO, which are taken against the infringing State; the increase in tariffs and the application of means of prohibition and restriction through its quotas, licenses and other administrative restrictions when applied, shall be observed by observing the rules of international law.

These procedures are not handled by the DSB itself, but authorize the injured party at its request to do so and only convict in the event of violations, which consequently affect the effectiveness of the DSB.

It is also difficult to consider the extent to which the DSB is impartial, especially if this body operates within the framework of a global trade organization composed of Member States and the President including.

Where the interests are conflicting, in addition to the domination and dominance of the major powers on the organs of this organization. This dominance is one of the most serious destructive factors in the settlement of disputes, all of which affect the character of neutrality. ${ }^{1}$

Consultations at the mandatory stage may not be fair if solutions are found to the economic and political imbalance between the negotiating parties, which may comply with the conditions of the developed countries for fear of harming their economic interests.

With regard to the independence of the DSB, this status may cease to exist in the case of backward or negative consensus. This is also evidenced by its structure and organizational structure because there is a formal separation between the Dispute Settlement Body and the General Council of the Organization, where each body has its own independent President.

The negative approach to consensus and decision-making in the WTO, especially within the settlement system, is by consensus or the so-called negative consensus. Any adoption of a resolution under the OPCW is virtually automatic. The only way that might impede the adoption of the resolution would be unanimous approval by the member states of the organ, including the complaining State.

This means that if only one country does not agree to the negative consensus and does not join the resolution, the resolution must be adopted ${ }^{2}$

A key challenge to the WTO's Permanent Appellate Body is US reservations that could threaten and destroy the WTO dispute settlement system. ${ }^{3}$

The US disability related to Appellate Body appointments has reduced the number of seven members to just three (from the USA, China and India). ${ }^{4}$ This is the minimum requirement for the settlement of trade disputes before the WTO Dispute Settlement Body.

When the mandate of two of these three expires on December 10, 2019, there will be no legally existing appellate body to adjudicate disputes between WTO members.

The reservations raised by the United States of America several months ago are aimed at impeding the extension of the term of office of some members of the Appellate Body for a second session, or the appointment of new members to fill vacant posts. Some countries have described this current US tactic as obstructing appellate panel appointments as "taken as hostages". ${ }^{5}$ Ultimately, targeting the Appellate Body will destroy the entire WTO dispute settlement system.

The United States has opposed, because of its failure since July 2017, to approve the renewal or acceptance of new appointments to the Appellate Body.

The first difficulties emerged under the Obama administration in 2016, as the United States opposed the reelection of Korean member "Seung. Wha Chang". ${ }^{6}$ The post has been vacant since then. As well as the position

http://www.wto.org/english/tratop_e/dispu_e/disp_settlement_cbt_e/c1s1p1_e.htm last accessed on 25 December 2018.

${ }^{1}$ Chaalal Nawal, Settlement of Disputes within the World Trade Organization, Memorandum for Masters in Law, Faculty of Law and Political Science, Akli Mohamed and Lahj University, Bouira 2016, p. 63

${ }^{2}$ Galal Wafa Mohammadin, Settlement of International Trade Disputes within the GATT Agreement, New University Publishing House, Alexandria, 2004, pp. 29-30

3. Gantz, David A., An Existential Threat to WTO Dispute Settlement: Blocking Appointment of Appellate Body Members by the United States (July 15, 2018). Arizona Legal Studies Discussion Paper No. 18-26. Available at SSRN: https://ssrn.com/abstract=3216633 or http://dx.doi.org/10.2139/ssrn.3216633. Last accessed February 7, 2019.

4 . Ibid.

${ }^{5}$ Tetyana Payosova \& Gary Clyde Hufbauer \& Jeffrey J. Schott, (2018). "The Dispute Settlement Crisis in the World Trade Organization: Causes and Cures," Policy Briefs PB18-5, Peterson Institute for International Economics (2018).

${ }^{6}$ Primo Braga, B. M. Hoe (ed.), Future of the Global Trade Order, Florence : European University Instite 2th. Ed. 2017, p. 122; J. Bacchus, Might Unmakes Right. The American Assault on the of Law in World Trade, CIGI Papers no 173, May 2018, p. 22, [www. 
of two other members whose terms have expired, Mexican Ricardo Ramirez-Hernandez since June 30, 2017 and Belgian Peter Van den Bossche since December 11, 2017, and ended the mandate of S Baboo Chekitan Servansing, Republic of République de Mauric Mauritius on 30 September 2018 Who will most likely remain the current Indian President of the Appellate Body until December 10, 2019, Ujal Singh Bhatia, and American Thomas R. Graham, whose term expires on the same date as the Chinese Hong Zhao On November 30, 2020.

The United States offered several reasons to support its refusal to provide seats. It denounced the appeals court's alleged judicial activity against the United States and the systematic abuse of its mandate, as well as its responsibility towards members. ${ }^{1}$

The discussion then focused on questioning Article 15 of the Appeal Working Procedure, which states that a person who is no longer a member of the Appellate Body, with the permission of the Appellate Body and upon notification from the Board, may complete the examination of any appeal that was assigned to him when Only that person will still be considered as a member of the Appellate Body. The United States representative to the World Trade Organization cannot accept this principle.

The new member is the one who has the responsibility to continue to participate in the appeal procedures. ${ }^{2}$

\section{Conclusion}

Due to the inability of the GATT to settle trade disputes between the Contracting States due to its lack of obligation and the development of appropriate solutions and to deter States from taking unilateral and unilateral measures outside the scope of the Agreement.

A new round of negotiations was needed to overcome all previous difficulties, including the establishment of an effective dispute settlement system and the settlement of trade in services.

The scope of competence of the WTO Dispute Settlement Body. Its terms of reference may be determined in two respects: The first is disputes that arise between members of the organization due to breach of the agreement establishing the organization. The second is trade disputes arising from multilateral trade agreements.

Special teams also do not have the power to make final judgments in the disputes before them, but only to report on their findings in that dispute.

If courts are assigned a growing number of criminal cases, does this not mean that law and order are abused. On the contrary, this sometimes means that people have greater confidence in the courts and in the rule of law, and that the failure of the WTO serves no one, so that commercial disputes must be settled in accordance with internationally agreed rules.

\section{Recommendations}

1-The WTO should not consider the negotiation mechanism as a mandatory means of settling disputes before further action, but rather as an optional means.

2-Extending the jurisdiction of the Permanent Appeals Body to include all its material and legal aspects of the disputes submitted to it. The appeal of the reports of the Special Teams is not limited to the legal aspects, since commercial disputes are often confused so that it is difficult to distinguish between legal and factual, so it should have been an appeal to reconsider the dispute. In all its aspects.

3- The need to give special teams the power to make judgments in the disputes before them, and not just write a report of the results reached in that dispute.

4- The Dispute Settlement Body shall provide for the punishment or actions taken against the injuring State itself by providing a specialized executive body of the World Trade Organization to implement the decisions and recommendations in imposing the sanction or action against the causing State.

5- The WTO dispute settlement system should provide a compensation system for legal expenses and expenses incurred during the dispute.

6- WTO members should develop an effective means of reforming the crises that the WTO is going through, especially in the Feminist Dispute and Permanent Appeals Body. The reservations made by the United States of America, if they continue to do so, especially with regard to the appointment of new members of the Permanent Appellate Body, will inevitably lead to the destruction of an organ, system and a world trade organization that has maintained economic and trade stability among many countries by nearly Seventy years.

7- The need to amend the system of special treatment items among members, as a result of its negative effects on developing countries.

\section{References}

WTO Dispute Settlement: Statistics. Available on The WTO website :

Sites/default/files/documents/Paper\%20no.173.pdfl)..

${ }^{1}$ (v. G. Sacerdoti, The WTO in 2017 : Systemic Developments, Disputes and Review of the Appellate Body's and Panels Reports, Bocconi Legal Studies Research Paper Series, no3158379, April 2018, p.5 [https://ssrn.com/abstract=3158379]).

${ }^{2}$ WT/DSB/M/404, 6 mars 2018.\$7.6). 
https://www.wto.org/english/tratop e/dispu e/dispustats e.htm last accessed on 6 February 2019

https://www.wto.org/french/thewto_f/whatis_f/tif_f/disp1_f.htm

Available on The WTO website

http://www.wto.org/english/tratop_E/dispu_e/disp_settlement_cbt_e/c11s2p1_e.htm last accessed on 25 December 2018

Bahri A., "Using dispute settlement partnerships for capacity building: Bangladesh's triumphant experience at WTO DSU", (Journal of International Trade Law and Policy, 2019), Available on https://doi.org/10.1108/JITLP-07-2018-0028. last accessed on 7 February 2019

H T Pham, 'Developing counties and WTO the need for more mediation in the DSU', 9 Harv. Nrgot. L. Rev.347 2004.

Gantz, David A., An Existential Threat to WTO Dispute Settlement: Blocking Appointment of Appellate Body Members by the United States (July 15, 2018). Arizona Legal Studies Discussion Paper No. 18-26. Available at SSRN: https://ssrn.com/abstract=3216633 or http://dx.doi.org/10.2139/ssrn.3216633. Last accessed February 7, 2019

Tetyana Payosova \& Gary Clyde Hufbauer \& Jeffrey J. Schott, 2018. "The Dispute Settlement Crisis in the World Trade Organization: Causes and Cures," Policy Briefs PB18-5, Peterson Institute for International Economics.

Bossche, P., The Law and Policy of the World Trade Organisation 'Text, Cases, and Materials', (2nd ed, Cambridge University Press, 2009) page 172

Shaffer, Gregory C. and Elsig, Manfred and Puig, Sergio, The Law and Politics of WTO Dispute Settlement (March 16, 2016). The Politics of International Law, eds. Wayne Sandholtz \& Christopher Whytock, Oxford University Press, 2016; UC Irvine School of Law Research Paper No. 2016-10. Available at SSRN: https://ssrn.com/abstract=2748883 . last accessed on 7 February 2019

Leslie Johns and Krzysztof J. Pelc, "Fear of Crowds in World Trade Organization Disputes: Why Don't More Countries Participate?," The Journal of Politics 78, no. 1 (January 2016): 88-104.

Johns, L., Thrall, C. \& Wellhausen, R.L. Rev Int Organ (2019). https://doi.org/10.1007/s11558-019-09364-y

Yerxa, R., and Wilson, B., Key Issue in WTO Dispute Settlement: First Ten Years, (Cambridge University Press 2005) page 30 .

UNDERSTANDING THE WTO: SETTLING DISPUTES A unique contribution,Available on http://www.wto.org/english/thewto_e/whatis_e/tif_e/disp1_e.htm last accessed on 25 December 2018.

Tetyana Payosova \& Gary Clyde Hufbauer \& Jeffrey J. Schott, 2018. "The Dispute Settlement Crisis in the World Trade Organization: Causes and Cures," Policy Briefs PB18-5, Peterson Institute for International Economics.2018

https://www.wto.org/french/thewto_f/whatis_f/tif_f/disp1_f.htm

The World Trade Organisation, A Handbook on WTO Dispute Settlement System, Cambridge University Press. http://www.wto.org/english/tratop_e/dispu_e/disp_settlement_cbt_e/c1s1p1_e.htm last accessed on 25 December 2018.

Gantz, David A., An Existential Threat to WTO Dispute Settlement: Blocking Appointment of Appellate Body Members by the United States (July 15, 2018). Arizona Legal Studies Discussion Paper No. 18-26. Available at SSRN: https://ssrn.com/abstract=3216633 or http://dx.doi.org/10.2139/ssrn.3216633. Last accessed February 7, 2019.

Tetyana Payosova \& Gary Clyde Hufbauer \& Jeffrey J. Schott, (2018). "The Dispute Settlement Crisis in the World Trade Organization: Causes and Cures," Policy Briefs PB18-5, Peterson Institute for International Economics (2018).

Primo Braga, B. M. Hoe (ed.), Future of the Global Trade Order, Florence : European University Instite $2^{\text {th }}$. Ed. 2017, p. 122 ; J. Bacchus, Might Unmakes Right. The American Assault on the of Law in World Trade, CIGI Papers n 173, May 2018, p. 22, [www. Sites/default/files/documents/Paper\%20no.173.pdfl)..

v. G. Sacerdoti, The WTO in 2017 : Systemic Developments, Disputes and Review of the Appellate Body's and Panels Reports, Bocconi Legal Studies Research Paper Series, n³158379, April 2018, p.5 [https://ssrn.com/abstract=3158379]).

WT/DSB/M/404, 6 mars 2018.\$7.6). 